\title{
ISOLASI DAN IDENTIFIKASI KAPANG ENDOFIT DARI TANAMAN ALANG-ALANG (Imperata cylindrica (L.) BEAUV.)
}

\author{
Makhabbah Jamilatun ${ }^{1}$, Shufiyani ${ }^{1}$. \\ ${ }^{1}$ Jurusan Analis Kesehatan Poltekkes Kemenkes Banten \\ Korespondensi: makhabbah.j@gmail.com
}

\begin{abstract}
Endophyte microbes in plants can be various, one of which is endophytic fungi. Endophytic fungi are reported to produce bioactive metabolite. Many kinds of plants, especially herbal plants, can be used as the source of endophytic fungi. The potential herbal plant is cogon grass (Imperata cylindrica (L.) Beauv.). This study is to identify the presence and types of endophytic fungi of cogon grass (Imperata cylindrica (L.) Beauv.). This research was conducted by isolating endophytic fungi from cogon grass (Imperatacylindrica (L.) Beauv.) using the medium of Potato Dextrose Agar Chloramphenicol (PDAC), followed by purification of endophyte fungi and identification of isolates of endophytic fungi based on its macroscopic and microscopic properties. The results of this research found seven isolates of endophytic fungi in cogon grass (Imperatacylindrica (L.) Beauv.), which are 1 isolates of Fusarium sp. from the flowers, 2 isolate of Mucor sp. from the leaves, 3 isolates of Mucor sp. from the stems, 1 isolate of Mucor sp. from the roots.
\end{abstract}

Keywords: fungi, endophyte, cogon grass (Imperata cylindrica (L.) Beauv.)

\begin{abstract}
ABSTRAK
Mikroba endofit di dalam bagian tanaman dapat terdiri dari berbagai macam jenis, salah satunya yaitu kapang endofit. Kapang endofit dilaporkan menghasilkan berbagai metabolit bioaktif. Berbagai jenis tanaman terutama tanaman obat, dapat digunakan sebagai sumber isolat kapang endofit. Jenis tanaman yang berpotensi sebagai tanaman berkhasiat obat adalah alang-alang (Imperata cylindrica (L.) Beauv.).Tujuan penelitian ini adalah untuk mengetahui keberadaan dan jenis kapang endofit dari tanaman alangalang (Imperata cylindrica (L.) Beauv.). Penelitian dilakukan dengan mengisolasi kapang endofit dari tanaman alang-alang (Imperata cylindrica (L.) Beauv.). menggunakan medium Potato Dextrose Agar Chloramphenicol (PDAC), kemudian dilakukan pemurnian pada kapang endofit serta mengidentifikasi isolat kapang endofit berdasarkan ciri makroskopis dan mikroskopis. Hasil penelitian diperoleh tujuh isolat kapang endofit yang tumbuh pada tanaman alang-alang (Imperata cylindrica (L.) Beauv.), yaitu 1 isolat kapang Fusarium sp. dari bagian bunga, 2 isolat Mucor sp. dari bagian daun, 3 isolat Mucor sp. dari bagian tangkai, 1 isolat Mucor sp. dari bagian akar.
\end{abstract}

Kata kunci: kapang, endofit, alang-alang (Imperata cylindrica (L.) Beauv.) 


\section{PENDAHULUAN}

Resistensi antibiotik telah menjadi permasalahan di dunia seiring dengan meningkatnya penggunaan antibiotik. Hal ini memicu untuk dilakukannya eksplorasi terhadap sumber daya alam serta penemuan sumber antibiotik baru (Nirjanta, 2012), yang lebih efektif dan toksisitas rendah (Strobel dan Daisy, 2003). Penggunaan antibiotik alami lebih aman dan bisa diperoleh dari senyawa bioaktif dari alam (Radji, 2005).

Senyawa bioaktif sebagai sumber antibiotik dapat berasal dari beraneka ragam sumber daya alam, diantaranya dari tumbuhan, hewan, mikroba (Prihatiningtias, 2006). Mikroba penghasil senyawa bioaktif adalah mikroba endofit, mikroba yang berada di dalam jaringan tumbuhan hidup tanpa merugikan tumbuhan inangnya (Noverita et al., 2009). Perhatian terhadap mikroba endofit telah meningkat dalam beberapa tahun terakhir karena mempunyai beberapa fungsi, antara lain dapat menghasilkan berbagai senyawa fungsional metabolit sekunder berupa senyawa antikanker, antivirus, antibakteri, antikapang dan sebagainya (Strobel and Daisy, 2003; Noverita et al., 2009).
Mikroba endofit dapat ditemukan di dalam jaringan tumbuhan seperti biji, daun, bunga, buah, ranting, batang dan akar. Hubungan antara mikroba endofit dan tanaman inang merupakan bentuk simbiosis mutualisme, yaitu sebuah bentuk hubungan yang saling menguntungkan. Mikroba endofit memperoleh nutrisi dari tubuh tanaman inang, sebaliknya tanaman inang memperoleh proteksi terhadap patogen dari senyawa yang dihasilkan mikroba endofit (Rodriguez et. al., 2008).

Menurut Onifade (2007), mikroba endofit mampu menghasilkan senyawa bioaktif yang sama dengan tanaman inangnya. Hal ini terjadi karena adanya kemungkinan transfer genetik antara tanaman inang dan mikroba endofit, sehingga zat-zat yang bermanfaat di tanaman juga dapat dihasilkan oleh mikroba endofitnya. Jika mikroba endofit diisolasi dari tanaman obat maka senyawa metabolit sekunder yang dihasilkan sama seperti yang terkandung di tanaman inangnya. Hal ini merupakan peluang untuk mendapatkan sumber bahan obat yang alami, murah dan ramah lingkungan (Radji, 2005).

Mikroba endofit mempunyai arti ekonomis karena mikroorganisme 
merupakan organisme yang mudah ditumbuhkan, memiliki siklus hidup yang pendek dan dapat menghasilkan senyawa bioaktif dalam waktu cepat (Strobel and Daisy, 2003). Sehingga mikroorganisme dalam hal ini endofit perlu digali dan dikembangkan, mengingat kebutuhan bahan baku obat yang semakin meningkat baik jumlah maupun macamnya.

Mikroba endofit di dalam bagian tanaman dapat terdiri dari bermacam, salah satunya yang paling banyak diisolasi yaitu kapang endofit (Strobel dan Daisy, 2003; Rahmawaty, 2012). Kapang endofit merupakan golongan mikroba endofit yang paling banyak ditemukan dan terdapat dalam jumlah yang besar di alam ini. Besarnya perkiraan tersebut disebabkan satu spesies tumbuhan dapat dikolonisasi oleh satu atau beberapa kapang endofit (Dhanalakshmi et al. 2013).

Pencarian kapang endofit yang banyak terdapat pada tanaman dilakukan untuk memperkaya koleksi mikroba yang selanjutnya mikroba tersebut diidentifikasi untuk mengetahui sifat pertumbuhan dan jenisnya, sehingga dapat dimanfaatkan di bidang kesehatan. Tanaman dapat berpotensi sebagai obat karena mengandung senyawa aktif hasil metabolisme sekunder seperti alkaloid, steroid, terpenoid, flavonoid, saponin, glikosida, tanin, dan lain sebagainya (Wink, 2010).

Kapang endofit dilaporkan menghasilkan berbagai metabolit bioaktif, baik senyawa yang sudah dikenal maupun senyawa baru (Suryanarayanan, 2013). Beberapa penelitian melaporkan telah berhasil mengisolasi kapang endofit dari berbagai macam tanaman, diantaranya tanaman kunyit (Tiwit dkk., 2016), daun beluntas (Jessie dkk., 2016).

Dalam rangka mendapatkan senyawa bioaktif metabolit sekunder dari kapang endofit, salah satu pendekatan yang bisa digunakan adalah pemilihan tanaman inang yang telah diketahui memiliki bioaktivitas yang dimaksud. Berbagai jenis tanaman terutama tanaman obat, dapat digunakan sebagai sumber isolat kapang endofit. Salah satu jenis tanaman yang berpotensi sebagai tanaman berkhasiat obat adalah alang-alang (Imperata cylindrica (L.) Beauv.). Berberapa penelitian telah dilakukan untuk menyelidiki manfaat dari alang-alang, diantaranya bersifat antibakteri (Mulyadi dkk., 2013), antioksidan (Khaerunnisa, 2009). 
Hingga saat ini, publikasi tentang kapang endofit yang diisolasi dari alangalang (Imperata cylindrica (L.) Beauv.) masih terbatas dan belum ada laporan tentang kapang endofit yang diisolasi dari alang-alang (Imperata cylindrica (L.) Beauv.) yang tumbuh di Indonesia. Sedangkan banyak hasil penelitian menunjukkan bahwa habitat yang berbeda dapat menunjukkan jenis mikroba endofit dan senyawa kimia yang berbeda. Oleh karena itu pada penelitian ini dilakukan isolasi dan identifikasi kapang endofit dari tanaman alang-alang (Imperata cylindrica (L.) Beauv.) yang tumbuh di Neglasari, Kota Tangerang dengan tujuan untuk mengetahui jenis kapang endofit dari tanaman alang-alang (Imperata cylindrica (L.) Beauv.).

\section{METODE}

\section{Lokasi dan Waktu Penelitian}

Penelitian ini dilaksanakan pada bulan Maret - Agustus 2018. Sampel diambil dari Tanaman Alang-Alang (Imperata cylindrica (L.) Beauv.) yang Tumbuh di Neglasari Kota Tangerang. Bagian tanaman alang-alang yang digunakan adalah akar, tangkai, daun, bunga. Determinasi tanaman dilakukan di Herbarium Bogoriense Balitbang
Botani Puslitbang Biologi-LIPI Bogor. Isolasi dan identifikasi kapang endofit dilakukan di Laboratorium Mikrobiologi Jurusan Analis Kesehatan Poltekkes Kemenkes Banten.

\section{Bahan dan Alat Penelitian}

Bahan-bahan yang digunakan meliputi tanaman alang-alang (Imperata cylindrica (L.) Beauv.) yang tumbuh di Neglasari, Kota Tangerang, Media Potato Dextrose Agar (PDA), deterjen, larutan hipoklorit 1\%, alkohol 96\%, kloramfenikol, LPCB, spiritus, alkohol $70 \%$, aquades, tissue. Peralatan yang digunakan meliputi batang pengaduk, botol semprot, gelas kimia, labu erlenmeyer, neraca analitik, mikroskop, cawan petri, gelas ukur, rak tabung reaksi, botol tinta steril, ose, kaca objek dan kaca penutup, pinset, botol alkohol, pisau, plastik pembungkus, aluminium foil, kapas steril, kertas kopi, tabung reaksi, mikropipet dan tip, kertas label, spidol, gunting, dan penggaris.

\section{Pengambilan sampel}

Pengambilan sampel dilakukan dengan cara tanaman alang-alang diambil dari ladang alang-alang secara utuh seluruh bagian tanaman. Kemudian sampel tanaman alang-alang ditempatkan dalam wadah dan dibawa ke Laboratorium Mikrobiologi Jurusan 
Analis Kesehatan Poltekkes Kemenkes Banten.

\section{Isolasi Kapang Endofit}

Isolasi kapang endofit dari tanaman alang-alang (Imperata cylindrica (L.) Beauv. L) diawali dengan bagian akar, daun, dan bunga tanaman dicuci terlebih dahulu dengan air mengalir dan direndam dengan air deterjen yang dilanjutkan ke dalam larutan hipoklorit 5,25\% selama 1 menit, ke dalam alkohol 96\% selama 30 detik, dibilas dengan aquades steril sebanyak tiga kali. Isolasi Kapang endofit dilakukan dengan metode tanam langsung. Bagian dari tanaman alangalang (Imperata cylindrica (L.) Beauv.) dipotong berukuran $1 \mathrm{~cm} \times 2 \mathrm{~cm}$ menggunakan pisau steril. Potongan tanaman alang-alang (Imperata $\begin{array}{lll}\text { cylindrica (L.) Beauv.) itu } & \text { (L) }\end{array}$ diinokulasikan ke media PDA dalam cawan petri. Kemudian inkubasi selama 3-7 hari di suhu ruangan.

\section{Pemurnian Isolat Kapang Endofit}

Kapang endofit yang telah tumbuh pada media isolasi PDA, kemudian secara bertahap dimurnikan satu persatu. Masing-masing isolat murni kapang endofit yang diperoleh, kemudian dipindahkan ke dalam media PDA. Pemurnian ini bertujuan untuk memisahkan koloni endofit dengan morfologi berbeda untuk dijadikan isolat tersendiri. Pengamatan morfologi dilakukan kembali setelah inkubasi selama 3-7 hari, dan apabila masih ditemukan pertumbuhan koloni yang berbeda secara makroskopik maka dipisahkan kembali sampai diperoleh isolat murni.

\section{Identifikasi Kapang Endofit}

Isolat diidentifikasi berdasarkan ciri-ciri makroskopis dan mikroskopisnya. Pengamatan makroskopis berdasarkan morfologi kapang meliputi warna dan permukaan koloni. Pengamatan mikroskopis berdasakan pengamatan preparat meliputi bentuk hifa serta bentuk sel reproduksi. Seluruh hasil pengamatan, selanjutnya dibandingkan dengan literatur dari David et.al., (2007) untuk mengetahui identitas kapang tersebut.

\section{Analisis Data}

Data hasil penelitian disajikan secara deskriptif dalam bentuk tabel ataupun gambar.

\section{HASIL DAN PEMBAHASAN}

Tabel 1. Jenis Kapang Endofit dari Tanaman Alang-Alang (Imperata cylindrica (L.) Beauv.) 


\begin{tabular}{ccc}
\hline $\begin{array}{c}\text { Kode } \\
\text { Isolat }\end{array}$ & $\begin{array}{c}\text { Asal Bagian } \\
\text { Tanaman } \\
\text { Alang-alang } \\
\text { (Imperata } \\
\text { cylindrica } \text { (L.) } \\
\text { Beauv.) }\end{array}$ & $\begin{array}{c}\text { Jenis } \\
\text { Kapang }\end{array}$ \\
\hline Isolat 1 & Bunga & Fusarium $\mathrm{sp}$ \\
Isolat 2 & Daun & Mucor $\mathrm{sp}$. \\
Isolat 3 & Daun & Mucor $\mathrm{sp}$. \\
Isolat 4 & Tangkai & Mucor $\mathrm{sp}$. \\
Isolat 5 & Tangkai & Mucor $\mathrm{sp}$. \\
Isolat 6 & Tangkai & Mucor $\mathrm{sp}$. \\
Isolat 7 & Akar & Mucor $\mathrm{sp}$. \\
\hline
\end{tabular}

Dari tujuh isolat endofit yang ditemukan dari tanaman alang-alang, jenis kapang meliputi Fusarium sp. (Gambar 1.) dari bagian bunga alang-alang, dan Mucor sp. (Gambar 2.) Isolat endofit yang ditemukan dari tanaman alang-alang (Imperata cylindrica (L.) Beauv.) dapat dilihat pada Gambar berikut.

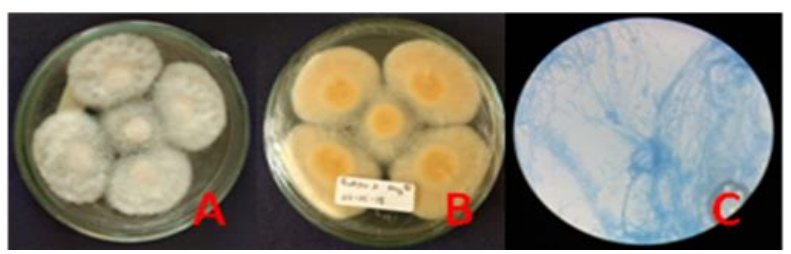

Gambar 1. (A). permukaan koloni kapang (B). dasar koloni kapang (C). mikroskopik kapang

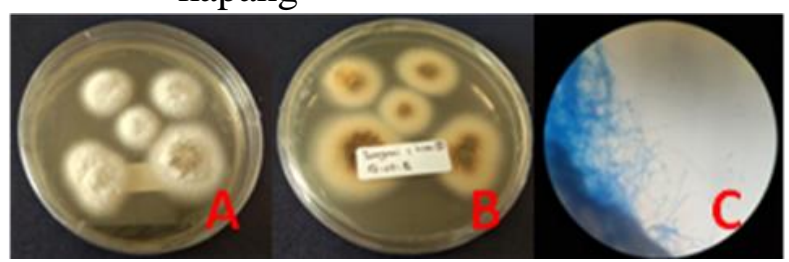

Gambar 2. (A). permukaan koloni kapang (B). dasar koloni kapang (C). mikroskopik kapang
Keberadaan kapang endofit yang ditemukan pada penelitian ini menunjukkan bahwa jenis kapang tersebut mampu memanfaatkan bahanbahan yang ada dalam jaringan tanaman alang-alang untuk kehidupannya. Kapang dapat masuk ke dalam tanaman dengan cara masuknya hifa ke dalam akar melalui rongga intrasel epidermis sehingga mengakibatkan sel akar berlubang dan terjadinya penetrasi hifa (Handayani, 2011 dalam Rahmahwaty, 2012).

Dari tujuh isolat endofit yang ditemukan dari tanaman alang-alang, jenis kapang meliputi Fusarium sp. (Gambar 1.) dari bagian bunga alangalang, dan Mucor sp. (Gambar 2.) yang ditemukan dari bagian daun, tangkai dan akar tanaman alang-alang. Isolat yang terlihat pada gambar 1. memiliki ciri warna permukaan putih dan warna dasar kuning, tekstur cottony, tepi tidak rata, permukaan gelombang timbul, pola pertumbuhan koloni menyebar. Hal ini sesuai dengan literatur, yang menunjukkan bahwa kapang tersebut termasuk Genus Fusarium (David et.al., 2007). Isolat yang terlihat pada gambar 2. memiliki ciri permukaan putih dan warna dasar putih krem bagian dalam, tekstur cottony-powdery, tepi rata, 
permukaan gelombang timbul, pola pertumbuhan koloni menyebar. Hal ini sesuai dengan literatur, yang menunjukkan bahwa kapang tersebut termasuk Genus Mucor (David et.al., 2007).

Berdasarkan hasil penelitian sebelumnya, spesies-spesies kapang endofit yang ditemukan dalam tanaman alang-alang, juga ditemukan sebagai kapang endofit pada tanaman lainnya sehingga dapat memperkuat adanya hasil penelitian ini. Beberapa hasil penelitian menyebutkan bahwa, spesies kapang endofit Fusarium sp. pernah ditemukan dari tanaman lengkuas merah (Kusumaningtyas et al., 2010), tanaman obat Antidesma madagascariense (Jeewon dkk., 2013), jeruk nipis (Suciatmih dkk., 2011), daun Dioscorea pentaphylla (Shankar \& Shashikala, 2010), pohon sengon (Sofiyani, 2014), pohon pisang (Souza et.al., 2014), tanaman padi, kopi, mawar (Hernando et. al., 2016), tanaman bayam (Sharma, 2015). Sedangkan kapang endofit Mucor sp. pernah ditemukan dari tanaman surian (Hafsari dan Isma, 2016), tanaman Arabidopsis arenosa (Rozpądek et. al, 2018). Penelitian yang dilakukan oleh Powthong et.al., (2013) dan Nur et.al., (2014), juga telah berhasil mengisolasi kapang endofit Mucor sp. dan Fusarium sp. dari tanaman obat famili leguminose, Sesbania grandiflora (L.) Pers.

Ditemukannya dua genus yang berbeda pada penelitian ini, yaitu Fusarium sp., dan Mucor sp., sesuai dengan pernyataan Noverita dkk. (2009), bahwa suatu tumbuhan inang dapat menghasilkan fungi endofit dengan jenis isolat yang berbeda dan jumlah bervariasi, hal ini merupakan mekanisme adaptasi dari endofit terhadap mikroekologi dan kondisi fisiologis yang spesifik dari masingmasing tumbuhan inang. Ditambahkan oleh Araujo, et al., (2002), habitat tanaman merupakan faktor lingkungan yang banyak mempengaruhi struktur dan komposisi spesies mikroba yang mengkolonisasi akar, batang, cabang dan daun. Sehingga adanya variasi isolat endofit bisa dipengaruhi oleh faktor lingkungan, selain itu juga interaksi dengan endofit atau patogen dalam lingkungan tersebut. Penelitian yang telah dilakukan oleh Shi et.al., (2018) dan Rozpądek et. al., (2018), menyebutkan bahwa keberadaan kapang endofit Fusarium sp. dan Mucor sp. berperan dalam menghasilkan metabolit sekunder, serta beberapa diantaranya 
berperan dalam adaptasi terhadap keracunan logam di dalam tanah.

\section{SIMPULAN}

Terdapat tujuh isolat kapang endofit yang ditemukan dari tanaman alangalang (Imperata cylindrica (L.) Beauv.). Jenis kapang endofit terdiri dari Fusarium sp. yang diisolasi dari bagian bunga dan Mucor sp. yang diisolasi dari bagian daun, tangkai serta akar tanaman alang-alang (Imperata cylindrica (L.) Beauv.).

\section{DAFTAR RUJUKAN}

Araujo, W. L., Marcon, J., Maccheroni Jr, W., van Elsas, J. D. \& Azevedo, J. L. 2002. Diversity of Endophytic Bacterial Populations and Their Interaction with Xylella fastidiosa in Citrus Plants. Applied and Environmental Microbiology. 68(10), 4906-4914. DOI: 10.1128/AEM.68.10.4906-4914.

David E., Stephen D., Helen A., Rosemary H., Robyn B. 2007. Descriptions Of Medical Fungi. Mycology Unit. Women's And Children's Hospital. School Of Molecular \& Biomedical Science. University Of Adelaide, Australia. The National Library Of Australia Cataloguing-InPublication.

Dhanalakshmi R, Umamaheswari S, Sugandhi P, Prasanth DA. 2013.
Biodiversity of the endphytic kapang isolated from Moringa oleifera of Yercaud Hills. Intl J Pharm Stud Res 4 (3): 10641068.

Hafsari, A.R. dan Isma A. 2016. Isolasi dan Identifikasi Kapang Endofit dari Tanaman Obat Surian (Toona Sinensis). Edisi Agustus 2013 Volume VII No. 2.

Hernando J., Christian J. OrozcoSanchez, Gesiane da Silva Lima and Gabriel Franco dos Santos. $2016 . \quad$ Endophytic Microorganisms Isolated of Plants Grown in Colombia: A Short Review. J Microb Biochem Technol, an open access journal Volume 8(6): 509-513.

Jeewon, R., Itto, J., Mahadeb, D., Jaufeerally, Y., Kai Wang, H., \& Rong Liu, A. 2013. DNA Based Identification and Phylogenetic Characterisation of Endophytic and Saprobic Fungi From Antidesma madagascariense, a Medicinal Plant in Mauritius. Journal of Mycology : 1-10.

Jessie Elviasari, Rolan Rusli, Adam M. Ramadhan. 2016. Identifikasi Metabolit Sekunder Dan Uji Aktivitas Antibakteri Isolat Jamur Endofit Daun Beluntas (Pluchea Indica (L.) LESS.). Jurnal Sains dan Kesehatan. 2016. Vol 1. No 5. 214 p-ISSN: 2303-0267, e-ISSN: 2407-6082.

Khaerunnisa, St., 2009, Pemanfaatan Senyawa Bioaktif dari Akar Alang-alang (Imperata cylindrica) sebagai Bahan 
Antioksidan, Universitas Airlangga.

Kusumaningtyas, E., Natasia, M., \& Darmono. (2010). Potensi metabolit kapang endofit rimpang lengkuas merah dalam menghambat pertumbuhan Escherichia coli dan Staphylococcus aureus dengan media fermentasiPotato Dextrose Broth (PDB) dan Potato Dextrose Yeast (PDY). Prosiding Teknologi Peternakan dan Veteriner Ramah Lingkungan dalam Mendukung Program Swasem-bada Daging dan Peningkatan Keta-hanan Pangan. Bogor. 819-824.

Mulyadi, Moh. Wuryanti, Purbowatiningrum Ria S. 2013. Konsentrasi Hambat Minimum (Khm) Kadar Sampel AlangAlang (Imperata cylindrica) Dalam Etanol Melalui Metode Difusi Cakram. Chem Info Vol 1, No 1, Hal 35 - 42.

Nirjanta Nameirakpam. 2012. Antimicrobial Properties Of Endophytic Kapang Isolated From Medicinal Plant Camellia Sinesis. International Journal Of Pharma and Bio Science 3 (3) : 420 - 427.

Noverita, Fitria, D. dan Sinaga, E. 2009. Isolasi dan Uji Aktivitas Antibakteri Jamur Endofit dari Daun dan Rimpang Zingiber ottensii Val. Jurnal Farmasi Indonesia. 4: 171-176.

Nur A., Muslim S., Muhammad J., Asman and M.Said B. 2014.
Isolation and identification of endophytic fungi from cocoa plant resistante VSD M.05 and cocoa plant Susceptible VSD M.01 in South Sulawesi, Indonesia.

Int.J.Curr.Microbiol.App.Sci (2014) 3(2): 459-467.

Onifade, AK. 2007, Research trends : Bioactive metabolites of fungal origin. Res. J. of Biol. Scie. 2 (1): $81-84$.

Powthong, P., B. Jantrapanukorn, A. Thongmee, and P. Suntornthiticharoen. 2013. Screening of Antimicrobial Activities of the Endophytic Fungi Isolated from Sesbania grandiflora (L.) Pers. J. Agr. Sci. Tech. (2013) Vol. 15: 15131522.

Prihatiningtias W dan M.S.H Wahyuningsih. 2006. Prospek mikroba endofit sebagai sumber senawa bioaktif. Jurnal online..

Radji, M. 2005. Peran Bioteknologi dan Mikroba Endofit dalam Pengembangan Obat Herbal. Majalah Ilmu Kefarmasian, Vol. II, No.3, 113 - 126.

Rahmawaty. 2012. Potensi Aspergillus niger dan Penicillium spp. Sebagai Endosimbion Pelarut Fosfat Pada Akar Serealia. [Skripsi]. Bogor : Institut Pertanian Bogor.9

Rodriguez, R.J., J.F. White, A.E. Arnold and R.S Redman. 2008. Fungal endophytes: diversity and functional roles. http://www.newsphytologis.org. 
Rozpądek., P., A. Domka, R. Ważny, M. Nosek, R. Jędrzejczyk, K. Tokarz, K. Turnau. 2018. How does the endophytic fungus Mucor sp. improve Arabidopsis arenosa vegetation in the degraded environment of a mine dump?. Environmental and Experimental Botany 147 (2018) $31-42$.

Shankar, NB \& Shashikala, J. 2010.Diversity and Structure of Fungal Endophyte in some Climbers and Grass Species of Malnand Region, Western Ghats, Southern India. Mycosphere 1(4):265-274.

Sharma, S. and Shikha Roy. 2015. Isolation and Identification of a novel Endophyte from a plant Amaranthus spinosus.

Int.J.Curr.Microbiol.App.Sci (2015) 4(2): 785-798.

Shi, S., Yuanyuan L., Yue M., Chenwen L., Ziwei L., Jianhong C. and Minghe L. 2018. Biological Activity and Chemical Composition of the Endophytic Fungus Fusarium sp. TP-G1 Obtained from the Root of Dendrobium officinale Kimura et Migo. Rec. Nat. Prod. 12:6 (2018) 549-556.

Sofiyani,F. 2014. Identifikasi Isolat Jamur Endofit Pohon Sengon Provenan Wamena Berdasarkan Analisis RDNA ITS. Skripsi. Prodi Biologi. Fak SainTek. UIN Suka Yogyakarta.

Souza, A., J.C. Cruz, N.R. Sousa, A.R.L. Procópio and G.F. Silva.
2014. Endophytic bacteria from banana cultivars and their antifungal activity. Genetics and Molecular Research 13 (4): 8661-8670 (2014)

Suciatmih, dkk. 2011. Isolasi, Identifikasi, Dan Skrining Jamur Endofit Penghasil Agen Biokontrol Dari Tanaman Di Lahan Pertanian Dan Hutan Penunjang Gunung Salak. Jakarta: UI.

Suryanarayanan, T.S. 2013. Endophyte research: going beyond isolation and metabolite documentation. Fungal Ecol., 6:561-568.

Strobel G. and Daisy B. 2003. Bioprospecting for microbial endophytes and their natural products. Microb Mol Biol Rev: 491-502.

Tiwit Widowati, Bustanussalam, Harmastini Sukiman dan Partomuan Simanjuntak. 2016. Isolasi Dan Identifikasi Kapang Endofit Dari Tanaman Kunyit (Curcuma longa L.) Sebagai Penghasil Antioksidan. Biopropal Industri Vol. 7 No.1.

Wink, M. 2010. Biochemistry of Plant Secondary Metabolism. USA: John Wiley \& Sons. 